\title{
PENERAPAN THEORY OF CONSTRAINT PADA KEPUASAN KERJA KARYAWAN RUMAH SAKIT MATA UNDAAN SURABAYA
}

\author{
THEORY OF CONSTRAINT APPLICATION ON EMPLOYEE SATISFACTION IN UNDAAN EYE HOSPITAL \\ SURABAYA
}

\author{
Selviana Putri Larasati, Setya Haksama \\ Fakultas Kesehatan Masyarakat, Universitas Airlangga, Surabaya \\ E-mail: selviana.larasati@gmail.com
}

\begin{abstract}
The level of job satisfaction in Undaan Eye Hospital had fluctuating trend since 2012 to 2015. The level of job satisfaction in 2015 was $77,80 \%$ that had not reached the target of $80 \%$. The aim of this study was to analize job satisfaction using theory of constraint in Undaan Eye Hospital. This study was an cross sectional observational study. The sample size of this study were 57 employee which were selected using simple random sampling technique $(\alpha=0.05)$. Health insurance was found as constraint in organizational factor with constraint value of 129. Not only helath insurrance but also career development was found as constraint in organizational factor with constraint value of 132. In the other hand, atmosphere of workplace was found as constraint in work environment with caonstraint value of 141. It can be concluded that efforts should be made to improve employee job satisfaction in Undaan Eye Hospital is to pay attention to health insurance, career development, and workplace atmosphere.
\end{abstract}

Keywords:constraint, job satisfaction, theory of constraint

\section{PENDAHULUAN}

Constraint atau kendala merupakan segala hal yang membatasi sistem, baik organisasi ataupun perusahaan dalam mencapai tujuan organisasi (Goldratt, 2004). Hansen dan Mowen (2007) berpendapat bahwa setiap organisasi memiliki keterbatasan sumber daya dalam setiap proses kegiatan mencapai tujuan. Keterbatasan itulah yang dimaksud dengan constraint.

Theory of constraintatau yang juga dikenal TOC merupakan suatu proses berpikir secara logis sistematis, dan terstruktur. Theory of constraint ini menjelaskan bahwa kinerja suatu organisasi pasti dibatasi oleh minimal satu constraint atau kendala (Dettmer, 1998). Teori ini mengakui bahwa kendala dapat membatasi apa yang dapat kita lakukan dalam situasi apapun serta dapat menyediakan solusi untuk memahami mengapa hal tersebut dapat terjadi dan menentukan langkah apa yang dapat kita lakukan untuk memperkecil kendala yang sedang dihadapi
(Pyzdek, 2000). TOC menekankan bahwa perbaikan constraint akan langsung memberikan perbaikan kinerja sistem secara menyeluruh (Sadat, 2009).

Teori ini dapat diterapkan pada seluruh sistem yang ada pada suatu organisasi. Dalam suatu sistem terdapat bermacam-macam saling ketergantungan yang secara relatif memiliki keanegaragaman yang tinggi (Cox \& Schleier, 2010). Di dalam suatu sistem terdapat banyak kegiatan yang berkontribusi terhadap kinerja suatu sistem. Kinerja suatu sistem akan tercapai jika kita memiliki waktu, uang, dan sumber daya manusia yang cukup. Di saat suatu organisasi tidak dapat melaksanakan seluruh kegiatan, di saat itulah perlu adanya pemfokusan terhadap hal-hal tertentu dan dilakukan perbaikan secara terus menerus (Goldratt, Cox, \& Whitford, 2004).

Kepuasan kerja merupakan sebuah sistem yang saling terkait yang pasti memiliki minimal sebuah constraintyang membatasinya. Kepuasan 
kerja merupakan sikap emosional yang menyenangkan dan mencintai pekerjaannya. Sikap tersebut dapat ditunjukkan dengan moral kerja, kedisiplinan, dan prestasi kerja. Kepuasan kerja dinikmati dalam pekerjaan, luar pekerjaan, dan kombinasi dalam dan luar pekerjaan (Hasibuan, 2006).

Sebagai salah satu rumah sakit berstatus paripurna, Rumah Sakit Mata Undaan berupaya melaksanakan indikator mutu baik di unit layanan maupun non pelayanan. Salah satu indikator mutu non pelayanan ialah kepuasan kerja. Setiap tahunnya Rumah Sakit Mata Undaan melakukan survei kepuasan kerja yang dilakukan pada seluruh karyawan tetap di Rumah Sakit Mata Undaan. Hasil survei kepuasan kerja pada tahun 2012 hingga 2014 menunjukkan bahwa tingkat kepuasan kerja karyawan yang ada di Rumah Sakit Mata Undaan belum memenuhi mencapai target yang ada yakni sebesar $80,00 \%$. Tingkat kepuasan kerja pada tahun 2012 hingga 2014 berturut-turut ialah 76,92\%, $78,92 \%$, dan $74,91 \%$.

Berdasarkan hasil penelitian yang dilakukan oleh Prasanti (2015) diketahui bahwa tingkat kepuasan kerja karyawan Rumah Sakit Mata Undaan Surabaya dengan kategori tinggi sebesar $77,80 \%$. Hal ini menunjukkan tingkat kepuasan kerja tersebut belum sesuai dengan target yang ada yakni sebesar $80,00 \%$

Penelitian ini bertujuan untuk menganalisis kepuasan kerja karyawan berdasarkan theory of constraint di Rumah Sakit Mata Undaan Surabaya. Penelitian ini diharapkan dapat menggambarkan kepuasan kerja sebagai suatu sistem yang dapat dibatasi oleh minimal satu kendala. Sehingga dapat diketahui kendala apa saja yang dapat mempengaruhi kepuasan kerja dan dapat menyusun upaya yang dapat dilakukan untuk memperkecil kendala tersebut.

\section{PUSTAKA}

\section{Kepuasan Kerja}

Mangkunegara (2002) mendefinisikan kepuasan kerja sebagai suatu perasaan yang menyokong atau tidak menyokong diri pegawai yang berhubungan dengan pekerjaannya maupun kondisi dirinya.Menurut Best dan Thurston dalam Saelan (2006), kepuasan kerja ditentukan oleh tiga faktor utama yakni faktor lingkungan kerja, faktor organisasi, dan faktor individu. Faktor lingkungan kerja yang dapat mementukan kepuasan kerja meliputi beban kerja, waktu kerja, keamanan tempat kerja, hubungan antar unit kerja, hubungan antar karyawan, hubungan dengan atasan, kelengkapan alat kerja, serta suasana tempat kerja. Faktor organisasi yang dapat menentukan kepuasan kerja meliputi jumlah gaji, struktur penggajian, insentif, tunjangan karyawan, jaminan kesehatan, jaminan pensiun, kebijakan manajemen, keterlibatan dalam organisasi, pelatihan, penghargaan atas prestasi, serta pengembangan karir. Sementara itu, faktor individu karyawan meliputi umur, pendidikan, masa kerja, jenis kelamin, serta status perkawinan.

\section{Theory of Constraint}

Theory of constraintsatau juga dikenal dengan TOC merupakan sebuah filosofi manajemen yang dikembangkan oleh Dr. Eliyahu M. Goldratt sejak tahun 1980-an. Theory of constraints 
didefinisikan sebagai suatu pendekatan ke arah peningkatan proses yang berfokus pada elemenelemen yang membatasi kinerja dalam peningkatan output (Cox \& Schleier, 2010). Proses yang ada dalam theory of constraint meliputi analisis causeeffect-cause, verifikasi dugaan, eksplorasi alternatif pemecahan masalah, serta proses perbaikan (Marton \& Paulova, 2010). Tujuan utama dari TOC adalah memaksimalkan efisiensi dari proses secara selektif di bagian paling kritis, sehingga dapat memaksimalkan kualitas kinerja organisasi.

Berdasarkan asalnya, Hansen dan Mowen (2007) mengelompokkan constraintatau kendala menjadi dua, yakni kendala internal dan kendala eksternal. Kendala internal merupakan faktor yang terdapat di dalam organisasi yang dapat membatasi kinerja organisasi tersebut. Kendala internal harus dimanfaatkan secara optimal untuk meningkatkan throughput semaksimal mungkin tanpa meningkatkan persediaan dan biaya operasional. Sementara itu, kendala eksternal merupakan faktor yang terdapat di luar organisasi yang dapat membatasi kinerja organisasi. Goldratt, et al. (2004) mengemukakan lima langkah dalam TOC yang dapat dijelaskan pada Gambar 1

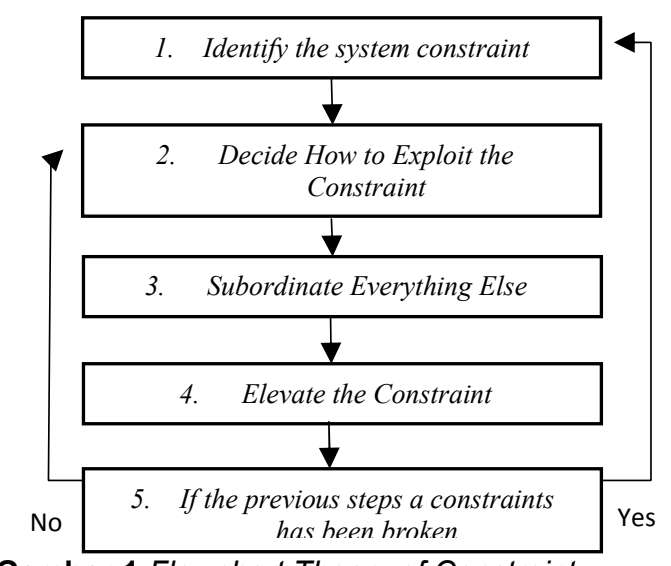

Gambar 1.Flowchart Theory of Constraint

Sumber: The Goal: A Process of Ongoing Improvement(Goldratt, et. al., 2004).

\section{METODE}

Penelitian ini merupakan jenis penelitian observasional tanpa melakukan intervensi pada populasi. Rancang bangun penelitian menggunakancross sectional.

Populasi dalam penelitian ini ialah karyawan tetap Rumah Sakit Mata Undaan yang memenuhi dua kriteria, yakni tidak masuk dalam jajaran struktural organisasi rumah sakit, serta karyawan yang memiliki masa kerja minimal satu tahun. Karyawan yang memenuhi kedua kriteria tersebut berjumlah 137 orang. Jumlah tersebut tidak termasuk dokter yang di Rumah Sakit Mata Undaan baik doker yang merupakan karyawan tetap maupun tidak tetap. Hal ini dikarenakan peraturan rumah sakit yang tidak mengizinkan untuk melibatkan dokter dalam penelitian. Besar sampel penelitian ini sebanyak 57 orang yang dipilih menggunakan teknik simple random sampling $(\alpha=0,05)$.

Pengumpulan data dilakukan dengan menggunakan kuisioner penelitian mengenai kepuasan kerja karyawan Rumah Sakit Mata Undaan Surabaya berdasarkan theory of constraint. Pada penelitian ini hanya membahas tentang internal 
constraint yang berhubungan dengan kepuasan dihitung dengan menggunakan nilai median kerja.Kategori constraint atau bukan constraint komposit.

Tabel 1.Constraint Kepuasan Kerja Karyawan Rumah Sakit Mata Undaan Surabaya pada tahun 2016

\begin{tabular}{|c|c|c|c|c|c|c|}
\hline \multirow{3}{*}{ Variabel } & \multicolumn{4}{|c|}{ Penilaian Responden } & \multirow{3}{*}{$\begin{array}{l}\text { Jumlah } \\
\text { Skor } \\
\text { Komposit }\end{array}$} & \multirow{3}{*}{$\begin{array}{l}\text { Kategori } \\
\text { Komposit }\end{array}$} \\
\hline & \multicolumn{2}{|c|}{$\begin{array}{c}\text { Tidak } \\
\text { Memuaskan } \\
\text { (Bobot 1) }\end{array}$} & \multicolumn{2}{|c|}{$\begin{array}{c}\text { Memuaskan } \\
\text { (Bobot 4) }\end{array}$} & & \\
\hline & f & Nilai & $\mathbf{f}$ & Nilai & & \\
\hline \multicolumn{7}{|l|}{ Faktor Organisasi } \\
\hline 1. Struktur Penggajian & 19 & 19 & 38 & 152 & 171 & Bukan Constraint \\
\hline 2. Insentif & 20 & 20 & 37 & 148 & 168 & Bukan Constraint \\
\hline 3. Tunjangan Karyawan & 14 & 14 & 43 & 172 & 186 & Bukan Constraint \\
\hline 4. Jaminan Kesehatan & 33 & 33 & 24 & 96 & 129 & Constraint \\
\hline 5. Jaminan Pensiun & 16 & 16 & 41 & 164 & 180 & Bukan Constraint \\
\hline 6. Kebijakan Manajemen & 16 & 16 & 41 & 164 & 180 & Bukan Constraint \\
\hline 7. Keterlibatan dalam Organisasi & 15 & 15 & 42 & 168 & 183 & Bukan Constraint \\
\hline 8. Pelatihan & 20 & 20 & 37 & 148 & 168 & Bukan Constraint \\
\hline 9. Penghargaan atas Prestasi & 24 & 24 & 33 & 132 & 156 & Bukan Constraint \\
\hline 10. Pengembangan Karier & 32 & 32 & 25 & 100 & 132 & Constraint \\
\hline \multicolumn{7}{|l|}{ Faktor Lingkungan Kerja } \\
\hline 1. Beban Kerja & 12 & 12 & 45 & 180 & 192 & Bukan Constraint \\
\hline 2. Waktu Kerja & 9 & 9 & 48 & 192 & 201 & Bukan Constraint \\
\hline 3. Keamanan Tempat Kerja & 8 & 8 & 49 & 196 & 204 & Bukan Constraint \\
\hline 4. Hubungan antar Unit Kerja & 8 & 8 & 49 & 196 & 204 & Bukan Constraint \\
\hline 5. Hubungan antar Karyawan & 3 & 3 & 54 & 216 & 219 & Bukan Constraint \\
\hline 6. Kelengkapan Alat Kerja & 18 & 18 & 39 & 156 & 174 & Bukan Constraint \\
\hline 7. Suasana Tempat Kerja & 29 & 29 & 28 & 112 & 141 & Constraint \\
\hline
\end{tabular}

Variabel dengan rentang nilai komposit 57-142,5 dikategorikan sebagai constraint. Sementara itu, variabel dengan rentang nilai komposit 143-228 dikategorikan sebagai bukan constraint.

\section{HASIL DAN PEMBAHASAN}

Langkah pertama dalam tahapan Theory of Constraint ialah penentuan kendala. Penentuan kendala dilakukan dengan menghitung nilai constraint dari masing-masing variabel yang ada. Pada penelitian ini hanya membahas tentang internal constraint yang berhubungan dengan kepuasan kerja. Hasil perhitungan nilai constraint dapat dilihat pada tabel 1.

Faktor organisasi merupakan elemen organisasi yang membentuk lingkungan kerja dan yang memfasilitasi atau mencegah karyawan mendapatkan apa yang penting bagi mereka dari pekerjaan mereka. Faktor organisasi penting untuk diketahui dikarenakan jika manajemen mengetahui faktor yang menentukan kepuasan kerja karyawan dalam konteks organisasi, maka manajemen organisasi akan dapat meningkatkan tingkat kepuasan kerja dengan memodifikasi faktor tersebut. Selain itu, faktor organisasi lebih dikendalikan oleh manajemen daripada faktor individu, sehingga dianggap lebih produktif untuk meningkatkan kepuasan kerja karyawan daripada mencoba untuk mempengaruhi faktor individu (Janićijević, et. al., 2015).

Berdasarkan tabel 1 dapat diketahui bahwa terdapat 2 variabel pada faktor organisasi dengan kategori constraint. Kedua variabel tersebut ialah variabel jaminan kesehatan dan pengembangan 
karir. Variabel jaminan kesehatan memiliki jumlah skor komposit sebesar 129 sedangkan variabel pengembangan karir memiliki jumlah skor komposit sebesar 132. Jumlah skor komposit masing-masing variabel tersebut kurang dari 142,5 sehingga dikategorikan ke dalam constraint. Delapan variabel lain pada faktor organisasi dikategorikan kedalam bukan constraint. Hal ini dikarenakan kedelapan variabel tersebut memiliki jumlah skor komposit lebih dari 142,5. Variabel tersebut ialah struktur penggajian, insentif, tunjangan karyawan, jaminan pensiun, kebijakan manajemen, keterlibatan dalam organisasi, pelatihan, serta penghargaan atas prestasi.

Jaminan kesehatan merupakan bentuk kompensasi non finansial yang didapatkan seorang karyawan. Jaminan kesehatan berupa pemenuhan kebutuhan kesehatan oleh organisasi untuk karyawan. Penelitian yang dilakukan oleh Adams dan Artz (2014) menyimpulkan bahwa kurangnya portabilitas asuransi kesehatan dan kebutuhan untuk menyediakan asuransi untuk keluarga mengarah ke pekerja berada di pekerjaan yang membuat mereka kurang puas.

Kadarisman (2012) mengatakan pengembangan karir merupakan usaha formal untuk meningkatkan dan menambah kompetensi/kemampuan, yang diharapkan berdampak pada pengembangan dan perluasan wawasan yang membuka kesempatan mendapatkan posisi/jabatan yang memuaskan dalam kehidupan sebagai pegawai. Upaya peningkatan pengembangan karir karyawan akan memberikan dampak yang positif dalam meningkatkan kepuasan kerja karyawan.

Muchlas (2005) dan Robbins

menyebutkan bahwa kesempatan untuk memperoleh promosi melalui jenjang kepangkatan (reward system) mempengaruhi kepuasan kerja karyawan. Karyawan berusaha mendapatkan kebijakan dari praktik promosi yang adil. Promosi memberikan kesempatan untuk pertumbuhan pribadi, tanggung jawab yang lebih banyak dan status sosial yang ditingkatkan, oleh karena itu individu-individu yang mempersepsikan bahwa keputusan promosi dibuat dalam cara yang adil (fair and just) kemungkinan besar akan mengalami kepuasan dari pekerjaan mereka. Penelitian Jahan dan Kiran (2013) berpendapat bahwa pada dimensi promosi pada Rumah Sakit pemerintah memiliki kepuasan kerja perawat yang lebih tinggi dibanding perawat yang bekerja di Rumah Sakit swasta.

Sementara itu, pada tabel 1dapat diketahui pula terdapat 1 variabel pada faktor lingkungan kerja dengan kategori constraint. Variabel tersebut ialah variabel suasana tempat kerja. Variabel suasana tempat kerja memiliki jumlah skor komposit sebesar 141. Jumlah skor komposit tersebut kurang dari 142,5 sehingga dikategorikan ke dalam constraint. Enam variabel lain pada faktor organisasi dikategorikan kedalam bukan constraint. Hal ini dikarenakan kedelapan variabel tersebut memiliki jumlah skor komposit lebih dari 142,5. Variabel tersebut ialah beban kerja, waktu kerja, keamanan tempat kerja, hubungan antar unit kerja, hubungan antar karyawan, serta kelengkapan alat kerja. 
Suasana tempat kerja yang nyaman sangat mempengaruhi kepuasan kerja seseorang. Apabila seorang karyawan tidak diberikan keleluasaan dalam mengatur layout tempat kerja tentunya akan menurunkan tingkat kepuasan kerja. Lingkungan kerja fisik mampu mengindikasikan kepuasan kerja karyawan dalam melaksanakan tugas. Manullang (2006) menyatakan baiknya peralatan yang digunakan dan perlindungan atas bahaya, sirkulasi udara yang baik, cukupnya penerangan atau pencahayaan dan keberhasilan, tidak hanya dapat meningkatkan efisiensi namun juga dapat menambah kegairahan dalam bekerja.

Langkah kedua dalam tahapan Theory of Constraint ialah menemukan solusi dari kendala yang telah ditemukan. Penelitian ini membahas internal constraint atau kendala internal pada kepuasan kerja sehingga dalam mengatasi kendala yang ditemukan dapat dilakukan dengan memaksimalkan sumber daya yang dimiliki.

Kendala yang ditemukan ialah belum sesuainya jaminan kesehatan yang diberikan oleh Rumah Sakit Mata Undaan Surabaya kepada karyawan. Selain itu karyawan juga merasa belum adanya kemudahan dalam pengurusan administrasi jaminan kesehatan yang diberikan. Hal ini dimungkinkan karena Rumah Sakit Mata Undaan baru menggunakan BPJS Kesehatan dalam memberikan jaminan kesehatan kepada karyawannya sehingga banyak karyawan yang belum memahami ketentuan BPJS Kesehatan secara mendalam, Solusi yang dapat diberikan ialah dengan memberikan pemahaman kepada karyawan tentang segala bentuk ketentuan dan administrasi yang terkait dengan BPJS Kesehatan sehingga karyawan dapat lebih mudah dalam menggunakan jaminan kesehatan yang diberikan. Pemahaman dapat dilakukan dengan bekerjasama dengan pihak BPJS Kesehatan. Selain itu, pihak manajemen rumah sakit juga dapat memberikan bantuan terkait pengurusan administrasi BPJS Kesehatan.

Faktor pengembangan karir ditemukan sebagai kendala lain yang mempengaruhi kepuasan kerja. Pengembangan karir merupakan salah satu hal penting yang perlu diperhatikan dalam meningkatkan kepuasan kerja. Upaya yang dapat dilakukan ialah dengan adanya keterbukaan informasi dan keadilan dari manajemen terkait peluang berkarir sesuai pendidikan karyawan. Selain itu, manajemen juga diharapkan lebih mendukung dan membantu karyawan guna pengembangan SDM yang lebih profesional.

Kendala yang ditemukan ialah belum tercapainya kepuasan karyawan terkait dengan suasana tempat kerja. Karyawan masih merasa penataan ruang kerja yang ada belum sesuai. Selain itu kondisi udara ruang kerja juga belum memberikan kepuasan kepada karyawan. Perlu adanya perhatian manajemen terkait sarana dan prasarana bagi karyawan disamping memperhatikan sarana prasarana untuk pasien. Apabila karyawan merasa nyaman dalam bekerja tentunya hasil kerja juga akan lebih optimal. Selain itu, manajemen juga perlu memperhatikan terkait perbaikan atau penggantian pendingin ruangan dan fasilitas pendukung kerja lainnya.

Upaya tersebut diharapkan dapat memperkecil kendala yang dapat menghambat 
tercapainya kepuasan kerja karyawan di Rumah Sakit Mata Undaan Surabaya. Apabila upaya yang telah diambil masih belum bisa mengatasi kendala yang ada maka dapat dilakukan evaluasi terkait proses maupun kebijakan yang ada.

Apabila upaya yang dilakukan dapat menyelesaikan kendala yang ada, maka tahap selanjutnya ialah kembali ke tahapan awal yakni identifikasi kendala. Identifikasi kendala dilakukan kembali untuk dapat mengetahui apabila terdapat kendala baru yang menghambat tercapainya kepuasan kerja karyawan. Hal tersebut sesuai dengan tahapan dalam Theory of Constraint yang merupakan siklus yang tidak terputus.

\section{SIMPULAN}

Jaminan kesehatan, pengemabangan karir, dan suasana tempat kerja ditemukan sebagai constraint yang dapat membatasi tercapainya kepuasan kerja. Perlu adanya pemahaman kepada karyawan terkait kebijakan dan administrasi terkait BPJS Kesehatan. Keterbukaan terkait dengan pengembangan karir juga sangat perlu dilakukan Adanya perhatian khusus terkait sarana dan prasarana perlu dilakukan sehingga dapat menunjang pekerjaan karyawan utamanya yang berhubungan dengan suasana tempat kerja.

Penerapan theory of constraint dalam kepuasan kerja telah dapat menggambarkan kepuasan kerja sebagai sebuah sistem yang dibatasi oleh minimal satu kendala. Namun, dalam menentukan suatu variabel dapat menjadi constraint atau bukan constraint belum adanya patokan yang jelas dalam teori tersebut. Sehingga perlu adanya penelitian mendalam terkait penerapan theory of constraint dalam kepuasan kerja.

Selain itu, klasifikasi jenis kendala yang ada masih terbatas pada pembedaan menjadi dua jenis kendala saja. Klasifikasi kendala tersebut dapat disesuaikan dengan jenis kendala yang lebih beragam. Misalnya dengan membedakan kendala menjadi tujuh jenis yaitu market constraint, resources constraint, material constraint, supplier constraint, financial constraint, knowledge constraint, dan policyconstraint.

\section{DAFTAR PUSTAKA}

Adams, S., \& Artz, B. (2014). Health Insurance, Familial Responsibilities, and Job Satisfaction. J Fam Econ Iss, I(36), 143153. doi:10.1007/s10834-014-9416-1

Cox, J., \& Schleier, J. (2010). Theory of Constraint Handbook. New York: McGraw Hill.

Dettmer, H. W. (1998). Constraint Theory: A LogicalBased Approach to System Improvement. In Breaking the Constraints to World-Class Performance. Milwauke: ASQ Quality Press.

Goldratt, E. M., Cox, J., \& Whitford, D. (2004). The Goal: A Process of Ongoing Improvement. Great Barrington: Gowen.

Hansen, \& Mowen. (2007). Managerial Accounting (8th ed.). New York: McGraw-Hill.

Hasibuan, M. P. (2006). Manajemen Sumber Daya Manusia: Pengertian Dasar, Pengertian, dan Masalah. Jakarta: PT Gunung Agung.

Jahan, T., \& Kiran, U. V. (2013). An evaluation of Job Satisfaction of Nurses across working sector. International Journalof Humanities and Social Science Invention, 2(6), 37-39. Dipetik Juni 22, 2016, dari www.ijhssi.org

Janićijević, N., Kovačević, P., \& Petrović, I. (2015). Identifying Organizational Factors of Job Satisfaction: The Case of One Serbian Company. Economic Annals, LX(205), 73104. doi:10.2298/EKA1505073J

Kadarisman, M. (2012). Manajemen Pengembangan Sumber Daya Manusia. Jakarta: Rajawali Press.

Mangkunegara, A. P. (2002). Manajemen Sumber Daya Manusia. Bandung: PT. Remaja Rosda Karya.

Manullang, M. (2006). Dasar-Dasar Manajemen. Yogyakarta: Gajah Mada University Press.

Marton, M., \& Paulova, I. (2010). Applying The Theory of Constraints in the Course of Process Improvement. Faculty of Mataerials Science and Technology in Tmava Slovak 
University of Technology in Bratislava(29), 71-76.

Muchlas, M. (2005). Perilaku Organisasi (Organizational Behaviour). Yogyakarta: PT Karipta.

Prasanti, A. P. (2015). ANALISIS PENGARUH PENERAPAN PRINSIP TOTAL QUALITY MANAGEMENT TERHADAP KEPUASAN KERJA KARYAWAN (Studi dilakukan di Rumah Sakit Mata Undaan Surabaya). Surabaya: Universitas Airlangga.

Pyzdek, T. (2000). The Complete Guide to the CQM. US: Quality America.
Robbins, P. S., Judge, T., Millet, B., \& Boyle, M. (2013). Organisational Behaviour (7th ed.). Australia: Pearson Education Australia.

Sadat, S. (2009). Theory of Constraints for Publicly Funded Health System. Toronto: University of Toronto. Dipetik Juli 19, 2016, dari https://tspace.library.utoronto.ca/bitstream/1 807/17826/1/Sadat_Somayeh_200906_PhD thesis.pdf

Saelan. (2006). Analisis Faktor yang Mempengaruhi Kepuasan Kerja Perawat. Jakarta.

Supriyanto, S., \& Ernawaty. (2010). Pemasaran Industri Jasa Kesehatan (1st ed.). Yogyakarta: Penerbit ANDI. 